Community and Exclusion: the Torrey Canyon disaster of 1967

\author{
Associate Professor Anna Green \\ Stout Research Centre \\ Victoria University of Wellington \\ Kelburn Campus \\ Wellington 6140 \\ New Zealand \\ Dr Timothy Cooper \\ University of Exeter \\ Centre for Environmental Arts and Humanities \\ Penryn Campus \\ TR10 9EZ \\ United Kingdom
}

This research was funded by British Academy Grant SG110572 


\section{Community and Exclusion: the Torrey Canyon disaster of 1967}

\section{Introduction}

What do environmental disasters mean, not least to the communities that experience them? What endures after a clean-up operation in completed, and why?

Multidisciplinary research into the impact of oil spills, in particular, often focuses upon the immediate aftermath, investigating the ecological damage, economic implications, media coverage, and psychological impact. More recently historians have begun to record the oral histories of earlier oil spills, such as the Exxon Valdez in Alaska, as well as the more contemporary Deepwater Horizon oil spill in the Gulf of Mexico. But there is, as yet, little analysis of how these kinds of disasters are remembered. ${ }^{1}$ In this article we examine the themes of community and exclusion in the case of one of Britain's biggest environmental disasters that took place nearly fifty years ago, the 1967 Torrey Canyon oil spill in Cornwall. It investigates the enduring impact and long-term meaning of the spill in community memory and narrative. We argue that environmental disasters cause more than just environmental damage. They also challenge communities, bringing to the fore latent tensions and conflicts between and within them. Furthermore, environmental disasters happen in particular social and political contexts, and it is in those contexts that their impact or meaning needs to be understood. What does this event reveal about community identity and community relations within Cornwall, and Cornwall's wider relationship with the British and global economy? And finally, what are the implications of the Torrey Canyon memories for our understanding of environmental disasters and crises? 
When the oil tanker SS Torrey Canyon, carrying 119,000 tons of Kuwait crude oil, became impaled upon the notorious Seven Stones reef close to the Scilly Isles and fifteen miles off the Cornish coast on 18 March 1967, it was at the time the 'largest shipwreck in history'. ${ }^{2}$ The crew were airlifted safely ashore, although one life was lost during the subsequent salvage attempt. ${ }^{3}$ The Labour government and marine experts, unprepared for an emergency on this scale and initially constrained by the shipowners' determination to salvage the vessel, struggled to respond effectively as oil began to leak into the sea from the breached oil tanks. Due to prevailing winds and exceptionally high spring tides the oil progressively fouled the beaches, coves and harbours around the northern coastline of Cornwall, Land's End and the Lizard, eventually reaching the coast of Brittany. Ultimately approximately 40 holiday beaches were seriously contaminated with the oil, and 'medium to heavy oil concentrations reached 80 per cent of the 25 coastal sites in Cornwall notified for wildlife protection. ${ }^{4}$ Concerned about the economic consequences of losing the vital tourist summer season the government launched a major military operation to break down the oil on the sea and on the beaches through the application of chemical detergents. After rough seas broke the ship in half, the decision was taken to bomb the vessel in an attempt to ignite and burn off the estimated 20,000 tons of oil that remained. Both oil and detergents killed tens of thousands of seabirds, damaged inshore fisheries, and destroyed the seawracks, anemones, sand eels, crustaceans and other life on rocks and foreshore. ${ }^{5}$

Comparatively little has been written about this disaster since an initial flurry of books published in the late 1960s. This is curious, as the Torrey Canyon was the first major spillage from a supertanker and is often identified as the key event in the making of modern British environmental consciousness. Contemporaneous narratives focussed 
upon causes, government intervention, and the scientific response to the contamination. ${ }^{6}$ More recent work has additionally addressed the role of the disaster in the subsequent expansion of maritime law and rehearsed the political response to the crisis. ${ }^{7}$ In both cases, the disaster is viewed from the centre, from the perspective of the British state and its particular interests and actions. ${ }^{8}$ The grounding has been similarly ignored by histories and social studies of Cornwall and Cornishness. It receives no mention at all in key texts on Cornish Studies, such as Payton's Cornwall: A History, or his important collection Cornwall Since The War. ${ }^{9}$ Even studies of Cornish tourism have neglected the impact of the Torrey Canyon, which, we show here, was mediated precisely through the 'tourist gaze' of popular concerns of the economic impact of polluted tourist beaches. ${ }^{10}$

The first accounts of the disaster therefore focus upon the decisions made in London and implemented by national institutions or bodies: the Labour government of the day; members of the national Committee of Scientists convened by Sir Solly Zuckerman; military personnel directing 'Operation Mop Up'; and, to a lesser extent, the Royal Society for the Protection of Animals and the Royal Society for the Protection of Birds. These accounts only occasionally make reference to the perspectives and experiences of the families, fishermen, hoteliers and others, who lived and made their living along these stretches of the Cornish coastline. Seeking to address this lacuna, a public call for memories of the Torrey Canyon generated more than one hundred responses, and the oral histories of fifty men and women were recorded in the summer of 2012. The cohort comprised men and women from a wide range of villages and towns in Cornwall, including a small number who were children or teenagers in 1967; personnel from the army, navy and fire service brought in from outside the county for the duration of the 
emergency; and visitors who saw some of the spectacle. The interviews followed an open-ended format in three parts: autobiographical information and life narrative, specific memories of the events and impact of the Torrey Canyon, and finally reflection upon the meaning of the oil spill in the longer term. ${ }^{11}$

\section{Remembering}

For an incident that only lasted, at most, a few weeks or months in the lives of the participants (although full ecological recovery took around twenty years or so) the memories are extraordinarily detailed and vivid. ${ }^{12}$ What might explain the strength of these memories? First of all, the senses, of sound, vision, touch, taste and smell, perform a significant function in prompting recall. The Torrey Canyon stories nearly always begin with a description of the smell, reflecting the 'Proust effect', the powerful role of smell in triggering memory. ${ }^{13}$ Many of those interviewed recalled being aware of the smell before hearing about the shipwreck or seeing the oil slick coming ashore. They described the smell of the oil as 'nauseous', 'a stench', 'foul', and 'pungent'.14 The oil was nearly always remembered as brown, in contrast to references in books and commemorative programmes to the 'black tide.' Interviewees drew upon a range of vivid visual metaphors and images to convey their shock at the sight of the oil, and the impact it had upon the sea. In Porthleven harbour the oil looked like 'melted chocolate', and in Marazion 'mulligatawny soup'; the oil made the 'sea shine' while 'subduing the waves'. ${ }^{15}$ The oil was 'thick, brown, stenchy muck ... like mud on top of the water.'16 One of the young firemen brought in from outside Cornwall to help with the clean-up described his first, unexpected, impression as follows:

there were virtually no waves ... you say you spread oil on troubled waters to smooth them, and it does, because this of course was thick crude oil. It 
was not black, it was chocolate brown, and ... it sort of subdued the waves so that they rippled in on to the beach and the next one would flow over the top of that, and when each wave receded it simply left the residue on the beach. So that was my first impression, it was not quite what we sort of thought it was going to be...'17

Houses and cottages along the coast were also coated with a fine film of oil, blown in on the wind, leaving 'swirls of colour and patterns on window panes'. ${ }^{18}$ These descriptions convey the initial shock experienced by those who smelt and witnessed the vast quantities of oil washing ashore.

But memory is also, as the pioneering theorist Frederic Bartlett reminded us, 'an effort after meaning'.19 Both appraisal theories of emotion and memory, and the social context in Cornwall, can provide insights into this process. While the links between emotional arousal and the encoding and retrieval of memories are well established, cognitive appraisal theories also suggest that 'people experience emotions when events are appraised as relevant to the status of some goal'. ${ }^{20}$ In other words, fear is evoked when 'goal failure is threatened but has not yet occurred', and anger when 'goals are obstructed and people believe that something can be done to reinstate the goal'.21 Both fear and anger were expressed through the Torrey Canyon oral histories, indicating that personal goals were either at risk or being thwarted. Fear emerged in response to the threat posed by the oil to local livelihoods; frustration and anger reflected the ways in which local knowledge was ignored and the community excluded during the clean-up operation. Stories and anecdotes about the Torrey Canyon therefore revolve around emotions of fear, frustration and anger, the latter expressed through a narrative peripeteia or 'an expectation gone awry'.22 As Douwe Draaisma has argued, memories 
that challenge our self-image or identity, such as affronts or humiliations, are especially durable. Furthermore, such memories have both an internal and external dimension: 'you have introspective access to the embarrassment, the rage and the confusion, all the feelings you know from the inside and remember as such. But the event is also stored as a registration of an outside event. The record sets down how others - or so you think looked at you when it happened.'23 The disdain evinced by politicians, scientists, and the hierarchy of the armed forces sent in to take control over the clean-up operation, has never been forgotten.

These negative encounters took on a particular meaning in the context of economic and social changes in Cornwall during the 1960s. Not least among these changes were the growth of tourism and the influx of second-home owners. Both of these developments enhanced, according to Bernard Deacon'...the cultural significance of what it meant to be "local"', thereby intensifying popular Cornish identity. ${ }^{24} \mathrm{~A}$ 'them' and 'us' dynamic of communal Cornish resistance to the dictates of an ignorant and bossy centralised government can be read throughout the oral histories. It is likely that the encounters with the state and its agencies during the Torrey Canyon disaster, in the context of environmental devastation, contributed to the growing sense of place and of difference, which are surely key dimensions of what Deacon describes as a popular sense of 'being Cornish'. These memories of difficult encounters with agents of the state retained relevance over the subsequent fifty years, especially for local people actively engaged in battles over other forms of pollution and environmental degradation, or observing debates over the Cornish language and regional identity. ${ }^{25}$ Further afield, every oil spill or disaster elsewhere in the world such as the Amoco Cadiz in 1978, Exxon Valdez in 
1989, the Braer in 1993, or the Deepwater Horizon oil spill of 2010, brought back memories of the Torrey Canyon and the impact it had upon the local community.

\section{Fear}

The first emotion felt by the local population was one of intense fear for their livelihoods. Economically dependent by the 1960s upon a successful summer tourist season of only a few weeks, the hoteliers and shopkeepers, as well as the men who fished close to shore for crab and shellfish, feared ruin. Derek Richards, a building labourer in his mid-twenties and living in Porthleven, recalled going to buy a newspaper from the local shop and hearing the owner shouting, 'we're finished, we're finished, the summer's gone, we've had it.' ${ }^{26} \mathrm{~A}$ young man working in the hotel run by his family remembered thinking that the oil would not dissipate and that they would go bankrupt. ${ }^{27}$ The 'hysterical atmosphere' in St Ives was recalled by a small shopkeeper, and others also remembered that people were 'frightened', 'panicking', and 'felt overwhelming fear'.28 Such fears, while not realised for most, were very real. In the post-war period Cornwall experienced a decline in the traditional industries of farming, extractive industries and engineering, and a rise in tourism. ${ }^{29}$ As Allan Williams and Gareth Shaw have shown, the 1950s saw the emergence of mass tourism in Cornwall and visitor numbers increased by $50 \%$ in the years between 1954 and $1964 .{ }^{30}$ By the 1960s some Cornish towns, such as St Ives, were increasingly dependent on this short seasonal tourist trade, and marked by its impact. However, the development of tourism was controversial, and it is far from clear that everyone benefited from its expansion.

Alongside these intense anxieties, the local seafaring community was deeply sceptical about the initial optimism by the shipowners, Union Oil of California, and the Dutch 
salvage company Wijsmuller that the ship could be floated off the rocks. Tony Farrell, sixteen years of age at the time and grandson of the St Ives' Harbour Master, sardonically remembered a lot of local chat 'that didn't think that would happen. But St Ives is very famous for its pessimism.' ${ }^{31}$ By the time this idea was abandoned, for as the community had anticipated the ship was securely pinioned on the sharp pinnacle of rock, a vast, continually expanding oil slick fanned out from the vessel. Six days after the grounding the biggest spring tide for fifty years deposited the thick crude oil high on the beaches, rocks and harbour walls. The policeman in the village of St Just in Penwith recalled the local people being 'very afeared of the oil coming ashore', and he sought volunteers to clear the oil from the cove. Sixty volunteers with their 'buckets and wellies' immediately responded, but the problem was beyond their capacity. ${ }^{32}$ It quickly became apparent to the local population that no one really knew what to do about it, not even the 'men in suits'.33

\section{Centre and Periphery}

It is at this point that one of the enduring themes of the oral histories begins to emerge in the narratives. The government took over operational authority, following ministers' perceptions of 'general incompetence' among the local councils, and in order to publicly demonstrate 'how the government was leading the fight against pollution'. ${ }^{34}$ As the scientists, and personnel from the army and navy, took control over the clean-up operation, local people in Cornwall were progressively sidelined. Their detailed knowledge of the local topography, winds and tides, coast and wildlife, was either not sought or largely ignored by those in charge both in London and on the ground. The perception of condescension and contempt from the incoming 'experts', politicians, and army officers, the humiliation at taking directions from those with far less local 
knowledge, has generated memories infused with a deeply ironic tinge. Even the terminology relating to attempts to remove the oil from the beaches diverges at this point: the Ministry of Defence term, 'Operation Mop-Up', was not mentioned by a single member of the oral history cohort. ${ }^{35}$

A range of strategies to contain or disperse the oil was generated from above, sometimes to intense criticism or derision from below. A young man visiting his grandmother in Sennen remembered 'the local fishermen saying that the navy should have put a fleet of auxiliary tankers alongside her to pump her out' during the first week of relatively settled weather. 'They knew that the fleet auxiliary was capable of transferring fuel to destroyers and ships at sea...' as they done so during the war. ${ }^{36}$ This plan of action had been rejected by the navy as too hazardous and slow, with the requisite equipment such as hoses not available. ${ }^{37}$ At stake in such encounters were competing claims to expert knowledge in which outsider expertise, dependent upon scientific and technological legitimation, was contrasted with an insider knowledge based upon everyday experience of sea, weather conditions, and the properties of oil. The decision to try and protect the harbours and beaches with booms floating on the sea also raised a 'wry smile' from local people: 'even a cursory glance by those of us who lived here, do they really think that's going to keep the oil out? When you think of a seascape that might have 15 or 20 foot waves, this mini plastic barrier which was only ... about six or seven inches high, it was kind of, it was never going to work. ${ }^{38}$ Nor did it. ${ }^{39}$ Attempts were also made to scrape the oil off the beaches with bulldozers, a method later endorsed as the least toxic option by marine biologists at Plymouth, but this had limited success and the oil still had to be deposited elsewhere. Bulldozers turned the beach at Porthmeor into a 'quagmire', remembered one resident who lived above the beach, disturbing and 
bringing to the surface the oil that had been under the wreck of the Alba since $1938 .{ }^{40}$ Elsewhere residents observed and regretted the erosion on the sand dunes caused by new beach access roads built for this purpose. ${ }^{41}$

The rejection of local knowledge was particularly acutely felt by those who made their living as seamen or fishermen. Seventeen years of age in 1967, David Stevens was working as a fisherman with his father in St Ives, and he recalled:

So as time went on we had these boffins sent down who had these wonderful ideas of how to disperse the slicks and we had one came down and we had to go out in our small boat, we had two small boats - the punt and the gig - and his idea was we had to go down to Zennor cove, pick up a couple of bales of straw from a farmer, this is in the boat, we had chicken wire mesh given to us, and we were to put the straw on the slick and then surround it with the wire mesh and set light to it. Well, if this scientist only knew, crude oil has to be kept warm in a tanker to be able to be pumped out, 'cause it's very thick. There's no way it was going to set light to it. But we had these weird and wonderful ideas coming down, and we had to accommodate them of course. ${ }^{42}$

Later he added, driving the point home: 'here's us humble fishermen and haven't got a clue about science, but knew the crude oil wouldn't catch fire.'43 He repeatedly returned to the theme, reiterating 'because I'm a fisherman, doesn't mean to say I'm a fool. But this is the way that they looked at it when they came down. We know more, we're greater than you, we know more than you'. Asked if it would have been better to take more account of local knowledge, he replied:

Oh definitely, because if you've worked a lifetime on the sea in around a certain coast, you gonna know each gully and each cove ... where you can take your boat, 
where you can't take your boat. So that knowledge is there, you pass your knowledge on.... And you know, yes, fishermen were superstitious and the old ancient folklores and all like that, but they were intelligent men. I mean, if you imagine taking a boat to sea with just a compass, and then bringing it back, it'd be no mean feat, is it? You know, there isn't many people could do that nowadays, is there? ${ }^{44}$

All the attempts to prevent the oil coming ashore, or clear it off the beaches once it had, generated stories about the ineffective schemes of the incoming scientific and military leaders in control of the operation, and the contempt displayed towards both local people and their seafaring knowledge.

Meanwhile, scientists in the local china clay industry, near St Austell, had immediately turned their minds towards finding a way to sink the oil so that it would be accessible for absorption by the micro-organisms on the sea floor. ${ }^{45}$ Brian Sheen, a chemical engineer with English China Clays, recalled immediately beginning experiments using a waste product from the China Clay process, a fine residue clay normally thrown away, to sink the oil and make it accessible to bacteria. ${ }^{46}$ Dried out and scattered on some oil, 'lo and behold, it actually did work, it sank'. The experiment was scaled to larger and larger tanks, where it continued to work. But the laboratory closed down for the Easter break, which fell six days after the grounding, 'and that broke the momentum, though it worked, we were getting there, so we never really pushed it right through'. Asked if the government expressed interest, he responded no, that at the time it had been thought that detergents were the only way and they were readily available. However, such a choice was not inevitable: when the oil approached the beaches of Brittany the French prioritized protection of their shellfish industry. Following a parallel line of thinking to 
that of the China Clay scientists, powdered Calcium Carbonate Chalk was used to successfully sink some of the oil and mechanical means were deployed for most of the remainder. ${ }^{47}$ When reviewing potential options available to the government, the official scientific report on the oil spill makes no mention of the China Clay initiative. ${ }^{48}$

The problem of oil pollution along the British coast was not new, but strategies to deal with it appear to have been largely drawn from research conducted, and products manufactured, by the oil industry itself. In 1962 the Department of Scientific and Industrial Research had produced a report on the removal of oil pollution from beaches, recommending that contaminated areas be treated with an emulsifier-solvent mixture, containing caustic coal tar naptha or kerosene, to break down the oil. The mixture of oil and detergent could then be hosed into the sea. 'All effective detergents', the report acknowledged, are toxic to marine and intertidal life, especially shellfish'. ${ }^{49}$ Nonetheless, the option of waiting for the natural action of tides and waves to gradually scour clean the beaches and rocks was not considered economically viable, especially given the exceptional height of the spring tide that deposited the oil. The economic value of the summer tourist season was given priority over the livelihoods of inshore fishermen, and the government took the decision to spray the oil with 'detergents', a term deceptively redolent of harmless washing up liquid.

At sea the detergent was sprayed on to the oil from booms mounted on the side of boats. Once the decision had been taken the local council started organizing the operation with the local fishermen, chartering both the large trawlers in Newlyn and the small launches of the crab and lobster fishermen. Again the geographical hierarchies of competing claims to expertise came into play. David Stevens recalled that when the government 
stepped in to fund everything an 'army bigwig' was sent down to take control over the operation from Penzance. David's father was instructed not to spray past St Ives' Head. Attempting to challenge this decision, he explained that the wind and tides would drive the oil slick on to Porthmeor Beach and sure enough:

Next morning we woke up and you could taste oil in your throat and the smell was awful, and we rushed down to the harbour in St Ives, and as we was passing Porthmeor Beach all the oil was in on Porthmeor Beach. ${ }^{50}$ Although David did not express any reservations about the value of spraying the oil on the sea, others clearly did. A Department of Labour report contains the following handwritten notation: 'there is a good deal of local doubt about the effectiveness of the sea spraying with detergent' which should be considered in any decision whether to continue spraying at sea. ${ }^{51}$ However, the spraying at sea continued. These decisions, both if to spray and where to spray, appear to have been taken largely without reference to the local community.

In some cases annoyance with the pompous self-important hierarchy controlling Operation Mop Up was expressed through anecdotes, in which the narrator appears as trickster hero getting 'one over' the officer in charge. Two such stories were narrated by a fireman in his mid-twenties, a Cornish native but at the time working in Gloucester. In total he spent about three separate weeks in Cornwall as part of the clean up operation, billeted at the Royal Air Force station St Mawgan. The following detailed anecdote follows comments about those in charge lacking geographical knowledge of the county: I think it was on my third week down, and of course by this time some of us were getting old hands at doing this, and we had an officer, he was actually from the Portsmouth Fire Brigade, and it was his first time down. He decided he was going 
to run this like a military operation. He had four appliances and himself with a Landrover, and we were going to Poldhu Cove on the Lizard. And he got us altogether at St Mawgan to start with, 'right, here's your details for the trip'. Basically, he wanted us to go out the gate at St Mawgan ... turn left...down the A39 to Indian Queens, [follow] the A30 all the way to Camborne, Camborne to Helston, Helston out on to the Lizard road, and down to Poldhu Cove. And ... the guy that was in charge of our truck said, 'is that the right way?' And I said 'No, no, we won't go that way.' So we made an excuse that the vehicle was difficult to start, so that we picked up the rear. And off he went, the officer in his Landrover, and three appliances, and then us following him. When we got to the main road we turned right, not left. We went quickly down through Newquay, along the Newquay to Redruth Road, and at Blackwater, on the old A30 of course... was Smoky Joe's Cafe. So we pulled into Smoky Joe's for breakfast. And we were sitting in there when somebody said, 'Oh look, the convoy's just going by'. So we let them go by, knowing that they had to go all the way down to Camborne, then Camborne to Helston. So we then ... went direct from Redruth to Helston through Four Lanes. As we came down into Turnpike, in Helston, lo and behold, there was the convoy coming up through Wendron Street, through the town centre, and we then picked up the rear.... I said to the other guys, 'look... there are two ways down to Poldhu... I suspect he [the officer in charge] will take the first turning'... which he did, and we drove on... and we were down on the Poldhu beach before he arrived. So we pulled on to the beach, leapt out, stripped off our tops and were lying down sunbathing when he arrived [laughter]. ${ }^{52}$

The stories of military, scientific and other failures and shortcomings during the Torrey Canyon disaster are nearly always imbued with a deep thread of ironic humour. This 
was undoubtedly one way to neutralise the exercise of self-important authority by those representing the interests of the state. Among the community there was, Tony Farrell recalled, a 'perverse jollity at the shambles of it all'.53

\section{Class and Community}

But if the local people felt marginalised by those in authority, their labour was nonetheless in demand to carry out orders from above. Who benefitted from the brief period of government largesse, through chartering their boats, or spraying the oil at sea or on the beaches, created tensions within communities deeply anxious about their economic survival. Opportunities existed for those owning boats of any kind to make an unexpected windfall from the disaster. The government chartered both large and small local boats and the pay rates were far in excess of what the owners or fishermen would normally earn. One young fisherman in Newlyn remembered making roughly $£ 9$ or $£ 10$ pounds for a six-day fishing trip on a trawler in his usual job, while he was paid $£ 15$ a day spraying the oil, and 'when I came ashore after two weeks I had a massive lump of cash in my hand. Nobody was used to that kind of money'. ${ }^{54}$ In practice, money earned by small local boats to spray the oil went some way towards compensating the inshore fishermen for loss of income over this period, and the work was fiercely protected. There was resentment, for example, when larger boats from other ports were brought in to spray 'our oil'. 55 One candidate for the St Ives' mayorality, Eric Kemp, then an officer with the Trinity House Steamship Vessel Service, recalled being intercepted on his way to a meeting at the Guildhall by two fishermen who vented their grievances:

When I got to the Guildhall door there's two fishermen standing there looking absolutely fed up with life... so, being a politician who wants to get elected, 'what's the matter?' 'Well, we come down here at half-past nine to see the mayor, because 
he said he'd see us. And when we got here at half-past nine, we were told he was busy with some meeting or other, and couldn't see us 'til one o'clock. And we're staying here waiting because we can't catch no fish, they're rolling drums down the cliffs into the coves and killing all the crabs and all our living. We can't go on the mackerel 'cause the market won't accept them because they say the sea is contaminated with oil. So we can't earn a living. And there's a fiddle going on in the harbour 'cause they're hiring boats at ... eighty or ninety pounds a day to go down the coast to Lands' End, and they're using small boats on the boom here, off the harbour. But when there's any wind the big boats can't operate, they're taking us off the boom and putting them on the boom, and of course they're getting eighty pounds a day and we're still capable of doing it for thirty'. ${ }^{56}$

Rumours abounded about who was making the most money out of the disaster. Tony Farrell worked on one of the small, inshore fishing boats spraying the oil. He recalled stories about the Sennen Cove men having made 'good money' by salvaging bits off the Torrey Canyon: 'there was certainly this wry humour about well, Sennen Cove men are making something out of it... they're getting on board and they're getting the compass, they're getting the electrics off, so there was a sense that even when the salvage men weren't there, Sennen Cove men were'. He thought that the overall feeling in the community was that 'at least we've made a bit of money out of it, and certainly some families did very well, one had a new boat within six months of it. For the bigger boats on spraying for a long time, it was a windfall.... There was also the sense that it is an awful disaster but at least some of us have got something out of it.' Again, the trickster narrative emerged in stories of local heroes seeing an opportunity in the clean-up operation. Farrell's grandfather, the Harbour Master in St Ives, also saw the opportunity 
to take advantage of government largesse and stockpile buoys, ropes, chains and other equipment for the local fishermen in the future. Even the Torrey Canyon lifeboat rations were snapped up, the tin of barley sugars fondly remembered by his grandson. ${ }^{57}$

The clean-up operation was consequently remembered as a 'bit of a gold mine for a while', and one father working for the local Council publicly acknowledged that the overtime generated by the 'golden oil' had helped to pay for his eldest daughter's wedding. ${ }^{58}$ But there were big differences in pay and not everyone experienced a temporary 'bonanza': those seconded from the Auxiliary Fire Service to spray the beaches worked long hours with no extra pay, nor was there a bonus for the soldiers sent down for the clean up operation. ${ }^{59}$ Soldiers made comparisons between the pay, living conditions and equipment of the British army on the job and those of the Americans seconded from the Third United States Air Force, leading to some altercations and punch-ups in the St Just pubs. ${ }^{60}$ The memories of the Torrey Canyon disaster, therefore, reveal the tensions generated by the assumption of control at national and elite level, and those arising within the community between those who stood to benefit from government largesse and those who did not.

While fishermen and those with boats were able to earn significant sums from the cleanup operation, those handling the detergents at sea and on the shore were exposed to potential physical harm. Initial advice from the Squadron Leader at RAF Newquay recommended that spraying at sea should cease due to 'dangers to life and limb', and in particular the risk of slipping and falling overboard. This advice was, 'perhaps for political reasons...not welcome', and second opinions were sought. ${ }^{61}$ Correspondence from the Ministry of Health suggests that medical advisers were partly flying in the dark 
in terms of potential health risks, lacking precise knowledge of the composition of the dispersants provided by the oil companies. For example, ten days after the grounding and well into the spraying programme, the Ministry of Health was informed by W.D. Buchanan of the Industrial Health and Safety Centre that he was unaware of 'any grounds for supposing the detergent will have a systemic effect, although I cannot rule it out', and went on to say that 'we have no details of the detergents in use nor could we pass them on ... even if we had'.62 It was very dirty, unpleasant work with men soaked in the chemicals by the end of the day, and one recalled going home with 'a real bad headache... your head was thumping that bad'.63 There was no protective clothing provided for many of those spraying the oil. On land the Royal Marines were given biological and chemical warfare suits and rubber boots to protect their uniforms, and the Auxiliary Fire Service used their own uniforms. ${ }^{64}$ Others, including men seconded from the National Trust in Cornwall and local fishermen, received nothing. ${ }^{65}$ Those who had direct contact with the detergent saw it leave 'burn' marks on the grass and foliage, perish rubber boots, destroy hoses, and strip the paint off boats or cars. ${ }^{66}$ The smell of the dispersant was considered to be even worse than that of the oil, and left men with sore throats and watering eyes. ${ }^{67}$

Despite only a few men experiencing serious health consequences at the time or later, it would appear that both army and local doctors feared the toxicity of the detergents. With the spraying programme underway on 27 March the Medical Officer of Health in Penzance informed the Industrial Health and Safety Centre that there had been cases of 'muscle cramps', with 'unconsciousness in one case' among the in-shore fishing fleet. ${ }^{68}$ The chaplain at the Seamen's Mission in Newlyn also recalled the Port doctor worrying about the effects of the detergent, and filling the small first aid station in the Mission 
with 'enough equipment for a small hospital, including oxygen cylinders'. ${ }^{69}$ Five potential 'risks' from the dispersant had been 'suggested' by the Department of Labour, including harmful effects of inhaling the 'airborne detergent', and exposure of the skin leading to dermatitis. ${ }^{70}$ Recollections of burning and dermatitis on the hands are the most common effects among those remembering handling the detergent. Only one, a young Royal Marine at the time, also remembered falling ill with pleurisy, which was attributed by the army doctor to his work on the Torrey Canyon clean-up operation. ${ }^{71}$ While the medical authorities were clearly concerned about the potential negative impact of the detergent upon health, and the military provided protective gear for the soldiers, this did not extend to the local community who handled the caustic detergent without warnings or clothing to shield them from the potentially harmful effects.

\section{Ecology and Community}

Despite the lack of information concerning the caustic and toxic nature of the detergents, the overall memory is of a sense of deep unease in the community at the 'sheer volume' being 'poured into Cornwall' by endless convoys of lorries carrying the drums for storage and distribution from local quarries. The perception that the detergent caused more damage to the foreshore than the oil is widespread among those remembering the affected beaches and coves. One soldier on the clean-up operation recalled spraying in Chapel Porth and observing the effects later while on patrol: 'it was like a Salvador Dali picture; we had bleached every bloody thing in sight, it was silver, it was absolutely incredible, we had killed everything... it was horrific. ${ }^{72}$ Where the rocky coves were inaccessible and soldiers were seen puncturing the drums of detergent and indiscriminately tipping the contents over the cliff on to the rocks below, the local policeman in St Just, for example, asked them to stop. ${ }^{73}$ The concern over the volume 
and indiscriminate application of the 'detergent' was shared by L.R. Benyon, a scientist in BP's Technical Development Division, who warned the manufacturers - BP, Esso and Shell - that 'it was only a matter of time before the press accused the oil companies... of profiteering from such extravagance and malpractice. ${ }^{74}$ It was officially estimated that two and a half million gallons of detergent were issued during Operation Mop-Up. ${ }^{75}$ The criticisms about the excessive use of detergents, and their destructive impact, are acknowledged in the Zuckerman report. ${ }^{76}$

The final sentence of this report also acknowledges the 'particularly unfortunate' effect of the oil and detergents on the seabirds. Along with the dead rock pools, the sight of thousands of oiled gannets, puffins, razorbills, guillemots, kittywakes, cormorants and others washed in with the tide remains vividly in the minds of those who recalled the immense efforts, usually in vain, to save the starving and dying birds. The official scientific report estimated that 20,000 Guillemots and 5,000 Razorbills were killed, plus smaller numbers of Shags, Puffins, Great Northern Divers and other species, decimating breeding colonies around the coast. ${ }^{77}$ The community responded by organizing their own collective efforts to clean and save the seabirds. Many of those interviewed recalled collecting oiled birds from the beaches, sometimes trying to wash the oil off at home (unless parents decreed otherwise) and putting them in boxes for collection and transportation to the Mousehole Bird Hospital. ${ }^{78}$ The birds also attracted the attention of journalists from newspapers and television, all seeking arresting images to symbolise the scale of this unprecedented oil spill. ${ }^{79}$ Derek Richards, a builder working for the local council and twenty-seven years of age at the time, remembered an encounter with national journalists on just such a mission. Searching the coves when the tide came in, with the support of his employer, he recalled that it was 'a horrible, horrible sight to see 
the birds.... When you picked them up they just died.... The shags, the puffins ... you'd see them flapping as they come in.... Me being an animal lover, it really hurt.' In Gunwalloe cove, which has a small church on the beach, he saw:

..these two newspaper guys come down with cameras. ... he wanted me to pick this little bird up which was covered in oil and put him on top of one of the crosses on the graves. So I just done it once, and he said, 'Oh, leave it there', and I said, 'no way, I'm not leaving that little bird... so I told him to B off ... and took it away. But they wanted me to leave it, and take all these photographs ... they didn't give a damn ... they just wanted a photograph for the papers. ${ }^{80}$

Once again the sense of outsiders with little knowledge or empathy comes into play.

\section{Community, Agency and Exclusion}

This study provides valuable insights both into the history of this environmental disaster in particular and remembering crises in general. The oral histories suggest that while the oil spill was emotionally very stressful, and considered a 'major tragedy' in terms of environmental pollution, the event has been partially contextualised and integrated into wider Cornish narratives. ${ }^{81}$ For example, the Torrey Canyon has become part of the shipwreck narrative in Cornish social memory. The grounding of vessels is far from unique in these notoriously dangerous waters: as one participant noted, 'the whole coast round there is littered with wrecks', some within living memory. ${ }^{82}$ Secondly, the disaster was perceived to have a 'silver lining' enabling fishermen and others to benefit from the brief windfall of government funds for the clean-up operation, earn overtime pay, or acquire materials unofficially salvaged from the ship. David, the young fisherman working alongside his father in 1967, located this dimension of the crisis within the vocabulary of 'wrecking' in Cornwall, the taking of materials and goods from 
vessels foundering along the coast. ${ }^{83}$ Finally, on the scale of Cornish shipping disasters, it was unanimously ranked well below the catastrophe of the Penlee Lifeboat Disaster some fourteen years later, in which sixteen people died including eight volunteer lifeboatmen from the community.

What could not be emotionally contained within existing social narratives was the imposition of quasi-wartime structures of authority and control during the response to the oil spill. The ways in which the clean-up operation was organised and implemented brought to the surface social contradictions and tensions, both national and local. Fears over the economic and environmental consequences of the disaster were compounded by the assumption of military authority and the marginalisation of local knowledge and concerns. The sense of exclusion is very powerful in these memories, reflected in the sardonic references to 'bigwigs', 'boffins', and 'men in suits', and the use of narrative devices such as irony, humour and trickster tales surely reflect the sense of disempowerment. As Draaisma reminded us earlier, challenges to self-image persist in memory and the antagonistic social interactions during Operation Mop Up created a disruption between self-image and external perception that was controlled and only partially neutralised through the expression of irony and humour. The Torrey Canyon disaster has a very different meaning in Cornish memory from conventional histories of national mobilisation that privilege the actions and perspectives of the national political, military and scientific elites.

What are the implications of the Torrey Canyon memories for the wider study of crises and disasters? Most crisis oral histories have focussed upon catastrophes: those atrocities and human conflicts that have entailed great loss of life, such as the Holocaust 
or one of the many bloody conflicts and human rights abuses during the closing decades of the twentieth-century. In the case of the latter, oral historians have also begun to record memories of such disasters as they happen, or in the immediate aftermath. ${ }^{84}$ In both these contexts of violence or immediacy individuals may struggle to make meaning out of the event and the concept of trauma dominates scholarly analyses. ${ }^{85}$ Trauma ruptures the relationship between the individual's internal and external worlds leaving individuals unable to reconcile past and present. Furthermore, these memories entail according to South African historian Sean Field, 'post-traumatic legacies such as dissociation, depression and hypersensitivity.' 86 Field rightly warns against the perception that all painful experiences are traumatic, and while the Torrey Canyon disaster caused great emotional distress at the time there is no indication that it resulted in traumatic memory. Nonetheless, the Torrey Canyon memories do share, at a different level of intensity, challenges to individual identity and agency.

There is, therefore, an explicit moral judgement embedded within the meaning of this environmental disaster, and this revolves around the interviewees' perceptions of intention. The oil spill was almost unanimously described as unintentional, an accident, even though our interviewees also recognized that managerial pressure - for example, to reach the final destination in time for the high tide - could lead to decisions that entailed an unacceptable level of risk. Attributing the disaster to human error enabled the event to be placed within existing narratives and discourses around shipwrecks and wrecking in Cornish history. Unintended accidents or human error do not challenge the moral orientation of memory, or disrupt the relationship between internal subjectivity and the external world, in the same way as intentional acts that are perceived to be destructive or damaging. The challenge to community and personal identities, through the 
usurpation of local hierarchies of knowledge by outsiders, falls into the latter category. We can only speculate about the extent to which the affronts and humiliations may have contributed to the growth of community solidarity and Cornish identity at a time when the growth of the tourist industry was reinforcing a sense of communal belonging and sense of difference. But there is little doubt about the sense of exclusion, as Eric Kemp, the Trinity House officer and mayoral candidate, commented during his interview, echoing the perspective of many of those recalling this event: 'There has been a tendency in Cornwall, still there today, never listen to the locals. No one wanted to listen....'87 The oral histories of the Torrey Canyon suggest that it is the nature of the social response to environmental disasters that may ultimately matter the most in community memory.

${ }^{1}$ For oral histories of the Exxon Valdez disaster, see Project Jukebox: Digital Branch of the University of Alaska, http://jukebox.uaf.edu/site7/exxonvaldez, accessed August 19 2014; and for the Deepwater Horizon oil spill, see The University of Southern Mississippi, Center for Oral History and Cultural Heritage, http://www.usm.edu/news/article/center-oral-history-documents-impact-2010-oilspill-gulf, accessed August 19 2014; for oral histories with children see, childrenofthespills.org, accessed August 192014.

${ }^{2}$ Colin Read, BP and the Macondo Spill: the complete story (Basingstoke, 2011), chapter 8. 
3 The only life lost in the disaster was that of Captain Hans Stal of the salvage company, killed in an explosion during the attempt to refloat the ship.

${ }^{4}$ National Archives [NA] Nature Conservancy Council, FT 48/29, Marine Oil Pollution Incident, report from D.S. Ranwell, 'Extent of Damage to Coastal Habitats due to the Torrey Canyon Incident', 42.

5 The figures in this paragraph are taken from The Torrey Canyon: Report of the Committee of Scientists on the Scientific and Technological Aspects of the Torrey Canyon Disaster (London, 1967), 5-9.

${ }^{6}$ See Richard Petrow, The Black Tide: In the Wake of the Torrey Canyon (London: Hodder and Stoughton, 1968); Edward Cowan, Oil and Water: the Torrey Canyon Disaster (London, 1969); J. McCaull, 'The Black Tide', Environment, 11 (1969): 2-16.

${ }^{7}$ Read, BP and the Macondo Spill; Norman A. Martínez Gutiérrez, Serving the rule of international maritime law: essays in honour of Professor David Attard (London, 2010); and John Sheail, 'Torrey Canyon: The Political Dimension', Journal of Contemporary History 42, 3 (2007) has recently revisited the political response to the crisis. 8 The public narrative has changed little since 1967: for example, 'The Torrey Canyon: the Toxic Tide', BBC Radio 4, March 26 2007, on the 40th anniversary of the disaster. ${ }^{9}$ Philip Payton, ed., Cornwall Since the War: The Contemporary History of a European Region (St Agnes, 1993).

10 Paul Thornton, 'Cornwall and Changes in the Tourist Gaze', Cornish Studies 1 (1993): 80-96.

${ }^{11}$ Interviews were recorded by[names deleted]. References to the oral history interviews are identified by name of interviewee, place and date of interview, time on recording (indexed in five minute segments). The recorded interviews are in the 
possession of the authors, and will be deposited (subject to any conditions specified on consent forms) in the Cornwall Record Office. Two interviewees requested anonymity and have been given pseudonyms.

12 S.J. Hawkins and A.J. Sutherland, 'The Torrey Canyon Oil Spill: Recovery of Rocky Shore Communities', in Restoring the Nation's Marine Environment, ed. Gordon W. Thayer (Maryland, 1992), 583-4.

13 Paula Hamilton, 'The Proust Effect: Oral History and the Senses', in The Oxford Handbook of Oral History, ed. Donald A. Ritchie (Oxford, 2012); Douwe Draaisma, Why Life Speeds Up As You Get Older: How Memory Shapes Our Past (Cambridge, 2004) chapter 3 .

${ }^{14}$ For example: Paul Pearson, Mullion Cove, May 30 2012, 5.00-10.00; Anna Hoare, St Stephen, June 12 2012, 5.00-1000; Shirley Jones, Plymouth, July 31 2012, 00.00-5.00; Antony Farrell, sound file 1, St Ives, May 28, 10.00-15.00.

15 Richard Dunstan, Camborne, June 22 2012, 5.00-10.00; Raymond Ireland, Mullion, June 1 2012, 10.00-15.00; Marion Caldwell, Crantock, July 17 2012, 10.00-15.00; Paul Leggo, Penzance, June 6 2012, 10.00-15.00;

${ }^{16}$ Derek Richards, Porthleven, June 31 2012, 00.00-5.00.

17 Eric Busby, Helston, May 30 2012, 15.00-20.00

18 Robert Cook, Truro, July 17 2012, 00.00-5.00.

${ }^{19}$ Frederic Bartlett, Remembering: A Study in Experimental and Social Psychology (Cambridge [1932] 1995), 227. See also Daniel L. Schacter, Searching for Memory: the brain, the mind, and the past (New York, 1996), 5; and Aikiko Saito, ed., Bartlett, Culture and Cognition (Philadelphia, 2000), 3. 
${ }^{20}$ Bob Uttl, Nobuo Ohta, and Amy L. Siegenthaler, eds, Memory and Emotion: Interdisciplinary Perspectives (Malden, MA, 2006), 45; see also Sven-Ake Christianson, ed., The Handbook of Emotion and Memory: Research and Theory (New York [1992] 2014); and Barbara A. Misztal, Theories of Social Remembering (Maidenhead, 2003), 80. 21 Ibid., 46.

22 Jerome Bruner, Making Stories (New York, 2002).

23 Draaisma, 46-7.

${ }^{24}$ Bernard Deacon, citing Herman Gilligan's research on social change in Padstow during this period, in 'And Shall Trelawney Die? The Cornish Identity', in Cornwall Since the War, ed. Philip Payton, 209.

25 Since 2002 Kernewek (the Cornish language) has been recognised by British Government under the European Charter for Regional or Minority Languages. On 24 April 2014 British government formally recognized the distinct identity of Cornish people: https://www.gov.uk/government/news/cornish-granted-minority-statuswithin-the-uk, accessed 6 August 2014.

${ }^{26}$ Richards, 00.00-5.00.

${ }^{27}$ Colin Kenney, Mullion, June 1 2012, 10.00-15.00.

${ }^{28}$ Sarah Thomson, Newlyn, June 4 2012, 20.00-25.00; Fred Stevens and Donald Ruhrmund, Hayle, July 25 2012, 35.00-40.00; Dennis Gover, Bickleigh, June 20 2012, 35.00-40.00; Kenney, 10.00-15.00.

${ }^{29}$ Deacon, p. 200.

${ }^{30}$ Allan M Williams and Gareth Shaw, 'The Age of Mass Tourism', in Cornwall Since the War, ed. Philip Payton, 87. 
31 Farrell, sound file 1,10.00-15.00. The pessimism of local opinion was also recorded in a letter regarding payment for vessels to spray the oil, see NA, Ministry of Agriculture and Fisheries, MAF 209/2710, Oil Pollution, Shipwreck of Torrey Canyon Oil Tanker, March 211967.

32 Tony Isaacs, St Austell, June 11 2012, 5.00-10.00.

33 Norman Harris, Camborne, June 19 2012, 15.00-20.00.

${ }^{34}$ Sheail, 491

35 NA, Ministry of Defence, DEFE 48/918, 1967, 'Operational Evaluation of the Torrey Canyon Incident: Operation Mop Up'.

${ }^{36}$ Robert Cook, Truro, July 17 2012, 5.00-10.00.

37 Cowan, 77

${ }^{38}$ Farrell, Sound File One, 25.00-30.00

39 The Torrey Canyon: Report of the Committee of Scientists on the Scientific and Technological Aspects of the Torrey Canyon Disaster, 28-30.

${ }^{40}$ Kemp, 35.00-40.00

41 Thomson, 10.00-15.00.

42 David Stevens, Penzance, July 26 2012, 00.00-05.00 and 05.00 - 10.00;

43 Stevens, 20.00-25.00.

${ }^{44}$ Stevens, $25.00-30.00$

45 The Cornish china clay industry, which mined kaolin for the production of porcelain, high quality paper and use in the building industry, was a major industrial employer in the region until the 1990s.

46 Brian Sheen, St Stephen, July 26 2012, 05.00-10.00. 
47 NA, Nature Conservancy Council, FT48/29, Marine Oil Pollution Incident, report by D.S. Ranwell, 'Extent of Damage to Coastal Habitats due to the Torrey Canyon Incident', 42; Petrow, 143-209.

48 The Torrey Canyon: Report of the Committee of Scientists on the Scientific and Technological Aspects of the Torrey Canyon Disaster, 25.

49 Ibid., 1

50 Stevens, 00.00-5.00.

${ }^{51}$ NA, Ministry of Labour, LAB 14/1912, 'The Suggested Hazards for Spraying Detergent at Sea', March 301967.

52 Busby, 20.00-25.00.

${ }^{53}$ Farrell, Sound File 2, 30.00-35.00; see also Philip Wrixon, Bodmin, June 11 2012, 10.00-15.00.

${ }^{54}$ Ray Tonkin, St Just, June 5 2012, 15.00-20.00

55 Farrell, sound file 1, 20.00-25.00

56 Eric Kemp, 35.00-40.00. For evidence of tainted fish see NA, Ministry of Housing and Local Government, HLG 120/1138, 'The Effects of Oil and Detergents on Marine and Wild Life', letter from Fisheries Laboratory, Ministry of Agriculture and Fisheries, May 141967.

57 Farrell, sound file one, 15.00-20.00 and 25.00-30.00; sound file two, 5.00-10.00.

${ }^{58}$ Alison Stuckey, Hayle, May 29 2012, 5.00-10.00; also Richards, 15.00-20.00.

${ }^{59}$ Geoffrey Miller, Lympstone, June 20 2012, 30.00-35.00; Gover, 40.00-45.00.

60 Richards, 5.00-10.00; Isaacs, 5.00-10.00.

${ }^{61}$ NA, Ministry of Labour, LAB 14/1912, Reports on occupational hazards of using detergent, 'Detergent Spraying of Oil Released from the Torrey Canyon', n.d.; Raymond 
Tonkin, 20.00-25.00, confirmed the 'slippery and slimy' decks during the spraying operation.

62 NA, Ministry of Labour, LAB 14/1912, letter from W.D. Buchanan to Dr J.M. Ross at the Ministry of Health, April 61967.

${ }^{63}$ Harris, 05.00-10.00

64 Gover, 5.00-10.00; Miller, 15.00-20.00; Ireland, 10.00-15.00.

65 Wrixon, 10.00-15.00; Farrell, sound file one, 15.00-20.00 and sound file two, 30.0035.00.

66 Tonkin, 10.00-15.00; Roger Bush, Penzance, June 7 2012, 15.00-20.00, 40.00-45.00; Kenney, 10.00-15.00, Vivian Stratton, St Ives, May 29 2012, 35.00-40.00.

${ }^{67}$ Kenney, 10.00-15.00.

${ }^{68}$ NA, LAB 14/1912, Detergent Spraying of Oil Released from the Torrey Canyon, letter from Medical Officer of Health, Penzance to the Medical Adviser, Industrial Health and Safety Centre, Ministry of Labour, March 271967.

69 Tony Gillman, Penzance, July 26 2012, 05.00-10.00.

70 NA, Department of Labour, LAB 14/1912, March 30 1967, 'Detergent Spraying of Oil From Torrey Canyon,' which includes a section on the 'The Suggested Hazards for Spraying Detergent at Sea'.

71 Gover, 10.00-15.00. Pleurisy is an inflammation of the lining around the lungs.

${ }^{72}$ Bush, 20.00-25.00.

${ }^{73}$ Isaacs, 10.00-15.00.

${ }^{74}$ Sheail, 495; a report in the Evening Standard, March 30 1967, drew attention to the increased revenue for Imperial Chemical Industries (ICI) from supplying large quantities of detergent for the clean-up operation. 
75 The Torrey Canyon: Report of the Committee of Scientists on the Scientific and Technological Aspects of the Torrey Canyon Disaster, 22.

76 Ibid., 48.

77 The Torrey Canyon: Report of the Committee of Scientists on the Scientific and Technological Aspects of the Torrey Canyon Disaster, 42.

78 Mousehole Bird Hospital was founded in 1928 by two sisters, Dorothy and Phyllis Yglesias; at the time of the Torrey Canyon it was run by the RSPCA, see http://www.mouseholebirdhospital.org.uk/ourhistory.php, accessed April 142014. The theme of community and environment is explored more fully in 'Rethinking Environmental Catastrophe: The Torrey Canyon Disaster and the Antinomies of Everyday Environmentalism', forthcoming.

${ }^{79}$ According to Kathryn Morse, the Torrey Canyon was the first instance where reports and images of oiled wildlife were also widely disseminated in the United States. See 'There Will Be Birds: Images of Oil Disasters in the Nineteenth and Twentieth Centuries', The Journal of American History 99, 1 (2012): 134.

${ }^{80}$ Richards, $10.00-15.00$ and 15.00-20.00.

${ }^{81}$ Kemp, 65.00-70.00.

${ }^{82}$ Richard Thatcher, Penzance, June 5 2012, 35.00-40.00.

${ }^{83}$ Stevens, 30.00-35.00.

${ }^{84}$ See Mark Cave and Stephen M. Sloan, eds, Listening on the Edge: Oral History in the Aftermath of Crisis (Oxford, 2014); Mary Marshall Clark, 'Case Study: Field Notes on Catastrophe: Reflections on the September 11, 2001 Oral History Memory and Narrative Project' in The Oxford Handbook of Oral History, ed. by Donald A. Ritchie (New York, 2011), 255-264; Sherna Berger Gluck, 'From California to Kufr Nameh and Back: 
Reflections on 40 Years of Feminist Oral History', and Luis van Isschot, 'The Heart of Activism in Colombia: Reflections on Activism and Oral History Research in a Conflict Area', both in Oral History Off The Record, ed. by Anna Sheftel and Stacey Zembrzycki (New York, 2013), 25-42 and 239-53.

85 See, for example, Kim Lacy Rogers and Selma Leydesdorff with Graham Dawson, eds, Trauma: Life Stories of Survivors (New York, 1999); Cathy Caruth, Unclaimed Experience: Trauma, Narrative, and History (Baltimore, 1996); and Lawrence L. Langer, Holocaust Testimonies: The Ruins of Memory (New Haven, CT: 1991).

86 Sean Field, 'Beyond "Healing": Trauma, Oral History and Regeneration', Oral History 34, 1 (2006): 31.

${ }^{87}$ Kemp, 50.00-55.00. Trinity House is the General Lighthouse Authority for England, Wales, the Channel Islands and Gibralter, see: http://data.gov.uk/publisher/trinityhouse-lighthouse-service. 